\title{
阿蘇九重地区の高原草地のネコブセンチュウ
}

\author{
後藤炤（九州農業試駼埸）
}

\section{Root-knot nematodes of the hilly grasslands in Aso-Kudju Plateau, Southern Japan}

\author{
Akira Goтон (Kyushu Agricultural Experiment Station)
}

Aso-Kudju Plateau is located in the central part of the northern Kyushu $\left(33^{\circ} \mathrm{N}, 131^{\circ} \mathrm{E}\right)$. Altitude ranges from $650 \mathrm{~m}$ to $900 \mathrm{~m}$, annual mean temperature is $12^{\circ} \mathrm{C}$ or less and volcanic ash soil covers the ground on the plateau. Clovers and graminaceous grasses such as orchardgrass and ryegrass were grown in plowed meadows and pastures, and vegetations of natural grasslands were of Miscanthus-, Imperata-, Zoysia- or Sasa-type. Survey of root-knot nematodes in this area was thought to be important not only from a viewpoint of grassland improvement but also from the ecology of the nematodes.

Researches were made extensively, covering six villages, and intensively in Sankyo Pastures in Oguni-machi, Kumamoto-ken. Several soil samples, including rhyzosphere soils of leguminous plants such as clovers or Lespedeza spp. in many cases, were collected in a given site and they were mixed into a pot, where seeds of the balsam were sown. Collections were made in 1968-1970, except in winter. Perineal patterns of female nematodes isolated from galls on the balsam roots were examined for identification of species.

Table 1 and Figure 1 show results of the survey. All specimens derived from natural and plowed grasslands in the plateau, i. e., from two locations in Kokonoe-machi, Oita-ken, two locations in Oguni-machi, Kumamoto-ken, two locations in Ichinomiya-machi, K-ken and four locations in Aso-machi, K-ken were identified as Meloidogyne hapla Chitwood, 1949. Also from grasslands at the foot of Mt. Aso was found $M$. hapla. In contrast with M. hapla, Meloidogyne incognita (Kofoid \& White, 1919) and Meloidogyne javanica (Treub, 1885) were found in maize and tobacco fields in some lower locations. The Meloidogyne-fauna of the hilly grasslands described here was peculiar in Kyushu, a warmer region of Japan, where M. incognita, M. javanica, M. hapla etc. were found commonly. In the present case, climatic influence was considered as a main factor on the distribution of $M$. hapla, $M$. incognita and $M$. javanica.

\section{調查目的および調查地の環境}

熊本県所在の阿蘇北外輪加ら大分罧の久住・飯田に至 る,ここで阿蘇九重地区の高原と呼ぶ場所は，ほぼ北緯 $33^{\circ}$, 東径 $131^{\circ}$ ，北部九州の中心部に位置し，標高 $650 \mathrm{~m}$ $\sim 900 \mathrm{~m}$ ，年㠽均気温は熊本県阿蘇郡小国町麻生釣の三 共牧場の九州農試観測定点 (標高 $650 \mathrm{~m}$ ) で $12^{\circ} \mathrm{C}$ 弱, そ饥 より高標高では $12^{\circ} \mathrm{C}$ をがるものと思われる。降水量は 年 $2,300 \mathrm{~mm}$ 程度で $6 \sim 7$ 月に最も多い(小国町もと林試小 国誠験地)。調查した自然草地は主として，ススキ型， チガヤ型，シバ型，ササ型で，ワラビ，八ギ類などを含 み, 人工草地（耕起非成草地）の植生は，クローバ類， オーチャードグラス，ライグラス類の鲲播によるもので

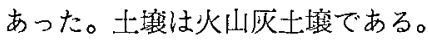

著者はこの地区の草地造成との関連で，被㕩が予想さ れるネコブセンチュウについて種とその分布を調查した が，この調查はまた線虫の生態的分布を破㚾するうえか らも舆味ある課題であった。なお本報の一部，自然草地 に関する部分は，牧野等本邦未耕地の植物寄生性線虫に 関する調查研究の第 3 報にあたる。

\section{調查法}

調查地点の設走：(1)一般調查は, 草地以外の参考調疽 も含めると，ほほ連繶する 6 力町村にわたった（第 1 表 参照)。(2)熊本県阿蘇郡小国町麻生釗の公営三共牧場で は,牧場内外にまんべんなく調査地点を配って, 集中調查 を行なった。そのなかでもとくに符 1 ，第 2 牧区（人工 草地）と，第 4 牧区相外自然草地についてはさらに詳し く調查した(第 1 図参照)。(3)参考のため，標高 $500 \mathrm{~m}$ 以 下の䇺地衫よび草地以外の耕地について，若干の調查を 行なった(第1表参照)。

材料採取, 種の同定：調疽点 (sampling site) では 域内の数点から採土し，土壤は混合して1袋（1標本） とした。採土にあたっては，ネコブセンチェウの各種が 第生するクローバ類，八ギ類のようなマメ科の根辺土腋 を可能なかぎり含ませた。採集は1968～1970年の間，冬 季以外の時期に行なった。採集した土塆好調查点別にポ ットに容れ，ホウセンカを播種し，その根に生じたゴー ルからネコブセンチュウの雌成虫を分離した。種の同定 は雌成虫の perineal patternによった。 
Table 1. Occurrence of Meloidogyne spp. in grasslands and other biotopes of Aso-Kudju Plateau and the neighbourhood.

\begin{tabular}{|c|c|c|c|c|c|c|}
\hline & ocation & Vegetation & Number & & $\begin{array}{c}\text { Number } \\
\text { of }\end{array}$ & \\
\hline $\begin{array}{l}\text { Prefecture } \\
\text { (County) } \\
\text { Village }\end{array}$ & Sampling place & $\begin{array}{c}\text { or } \\
\text { biotope }\end{array}$ & $\begin{array}{c}\text { of } \\
\text { samples } \\
\text { examined }^{t}\end{array}$ & Nematode & $\begin{array}{c}\text { samples } \\
\text { where the } \\
\text { species } \\
\text { was found }\end{array} \mid$ & Altitude \\
\hline Oita-ken & & & & & & \\
\hline $\begin{array}{l}\text { (Naoiri-gun) } \\
\text { Kudju-machi } \\
\text { (Kusu-gun) }\end{array}$ & $\begin{array}{l}\text { Prefectural Livestock } \\
\text { Experiment Station }\end{array}$ & $\begin{array}{l}\text { Fallow after } \\
\text { maize*2) }\end{array}$ & 1 & $\begin{array}{l}\text { incognita } \\
(?)\end{array}$ & 1 & $670 \mathrm{~m}$ \\
\hline Kokonoe-machi & $\begin{array}{l}\text { Ooishibaru } \\
\text { Zizobaru } \\
\text { Asozuru }\end{array}$ & $\begin{array}{l}\text { Natural grassland } \\
\text { Natural grassland } \\
\text { Cabbage field* }\end{array}$ & $\begin{array}{l}1 \\
1 \\
2\end{array}$ & $\begin{array}{ll}M, & \text { hapla } \\
M . & \text { hapla } \\
M . & \text { hapla }\end{array}$ & $\begin{array}{l}1 \\
1 \\
2\end{array}$ & $\begin{array}{l}800 \mathrm{~m} \\
800 \mathrm{~m} \\
700 \mathrm{~m}\end{array}$ \\
\hline Kumamoto-ken & & & & & & \\
\hline $\begin{array}{l}\text { (Aso-gun) } \\
\text { Oguni-machi }\end{array}$ & $\begin{array}{l}\text { Asozuru, } \\
\text { Sankyo Pastures } \\
\text { Do. } \\
\text { Do. } \\
\text { Foot of Mt. Waita }\end{array}$ & $\begin{array}{l}\text { Natural grassland } \\
\text { Do. }{ }^{4} \\
\text { Plowed grassland } \\
\text { Natural grassland }\end{array}$ & $\begin{array}{r}6 \\
6 \\
10 \\
2\end{array}$ & $\begin{array}{ll}M . & \text { hapla } \\
M . & \text { hapla } \\
M . & \text { hapla } \\
M . & \text { hapla }\end{array}$ & $\begin{array}{r}6 \\
6 \\
10 \\
2\end{array}$ & $\begin{array}{l}>650 \mathrm{~m} \\
\text { Do. } \\
\text { Do. } \\
750- \\
800 \mathrm{~m}\end{array}$ \\
\hline $\begin{array}{l}\text { Ichinomiya- } \\
\text { machi }\end{array}$ & $\begin{array}{l}\text { Shiroyama-tenbosho } \\
\text { Teno Pastures }\end{array}$ & $\begin{array}{l}\text { Natural grassland } \\
\text { Plowed grassland }\end{array}$ & $\begin{array}{l}1 \\
1\end{array}$ & $\begin{array}{ll}\text { M. } & \text { hapla } \\
\text { M. hapla }\end{array}$ & $\begin{array}{l}1 \\
1\end{array}$ & $\begin{array}{l}750 \mathrm{~m} \\
780 \mathrm{~m}\end{array}$ \\
\hline Aso-machi & $\begin{array}{l}\text { Shinmiya Pastures } \\
\text { Kabutoiwa Pastures } \\
\text { Matoishi Pastures } \\
\text { Television Tower } \\
\text { Kurumagaeshi }\end{array}$ & $\begin{array}{l}\text { Plowed grassland } \\
\text { Natural grassland } \\
\text { Natural grassland } \\
\text { Natural grassland } \\
\text { Natural grassland }\end{array}$ & $\begin{array}{l}1 \\
1 \\
1 \\
1 \\
1\end{array}$ & $\begin{array}{ll}M . & \text { hapla } \\
M . & \text { hapla } \\
M . & \text { hapla } \\
M . & \text { hapla } \\
M . & \text { hapla }\end{array}$ & $\begin{array}{l}1 \\
1 \\
1 \\
1 \\
1\end{array}$ & $\begin{array}{l}830 \mathrm{~m} \\
900 \mathrm{~m} \\
860 \mathrm{~m} \\
820 \mathrm{~m} \\
500 \mathrm{~m} *\end{array}$ \\
\hline Choyo-mura & $\begin{array}{l}\text { Yunotani Pastures } \\
\text { National Livestock } \\
\text { Breeding Farm } \\
\text { Nagano-buraku } \\
\text { Kita-buraku }\end{array}$ & $\begin{array}{l}\text { Natural grassland } \\
\text { Plowed grassland } \\
\text { Tobacco roots* } \\
\text { Maize field* }\end{array}$ & $\begin{array}{l}1 \\
1 \\
1 \\
1\end{array}$ & $\begin{array}{l}\text { M. hapla } \\
M . \text { hapla } \\
M . \text { javanica } \\
M . \text { incognita }\end{array}$ & $\begin{array}{l}1 \\
1 \\
1 \\
1\end{array}$ & $\begin{array}{l}750 \mathrm{~m} \\
550 \mathrm{~m} * \\
550 \mathrm{~m} \\
380 \mathrm{~m}\end{array}$ \\
\hline
\end{tabular}

1) Number of samples examined was the same to the number of sampling sites except in 4).

2) *: Survey for comparison.

3) Adjacent to Sankyo Pastures.

4) Examination in natural grassland adjacent to Pasture No. 4.

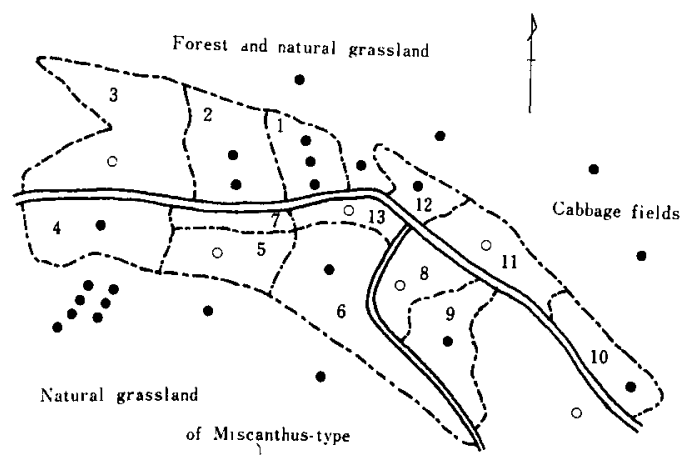

Fig. 1. Intensive survey of the root-knot nematodes in Sankyo Pastures (plowed grasslands of about $60 \mathrm{ha}$ ) and adjacent natural grasslands, Ogunimachi, Kumamoto-ken.

1) Figure indicates Pasture Number.

2) Meloidogyne hapla was found.

Specimens were insufficient to be identified.
調查結果

第 1 䘡および第 1 図に調査結果を示した。熊本県阿蘇 郡から大分県直入郡, 玫珠郡にいたる6 力町村の調查 で，標高 $650 \mathrm{~m}$ 以上の高原の人工草地（耕起造成草地） 4 地点，自然草地 9 地点から採集されたネコブセンチュ ウはことごとくキタネコブセンチュウ（Meloidogyne hapla Chitwood, 1949) であった。

一方，参考までに調査した熊本県小国町三共牧場に隣 接する部落 (大分県九重町) のキャベツ畑 2 点（標高約 $700 \mathrm{~m})$ ，阿蘇外輪下の熊本県阿蘇町車帰の自然草地 1 点 (標高 $500 \mathrm{~m}$ ), 同県長陽村阿蘇山麓（標高 $550 \mathrm{~m}$ ) の農 林省種畜牧場の人工草地 1 点からもキタネコブセンチュ ウが検出された。しかし，大分県久住町の県畜産試験場 のトウモロコシ跡（標高 $670 \mathrm{~m}$, 年平均気温 $11.5^{\circ} \mathrm{C}$ 前後) からはサッマイモネコブセンチュウ(?) (Meloidogyne incognita (Kofoid \& White, 1919)(?)), 熊本県長陽 村のトウモロコシ畑（標高 $380 \mathrm{~m}$ ）加らはサッマイモネ 
コブセンチュウ，同村長野部落（標高 $550 \mathrm{~m}$ ) のタバコ の根からはジゥワコブセンチェウ (Meloidogyne javanica (Treub, 1885)) を检出した。

熊本県小国町三共牧場における集中調盗（節 1 図）に よると，人工草地の 7 牧区, 自然草地の 6 地点加ら得ら れた材料はすべてキタネコブセンチュウであった。なお 第 1 , 第 2 牧区では人工草地を $2 \sim 3$ 分し, 第 4 牧区棚 外自然草地（ススキ型）では6点について調查ができた が，得られたネコブセンチュウはこの場合もことごと くキタネコブセンチュウであった。

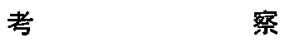

九州の低地の畑地などにはサツマイモネコブセンチュ ウ、ジャワネコブセンチュウ，キタネコブセンチュウな どが普通に分布しており（宮崎㖘試，1960，前原，1960， 横尾，1961, 後滕 (重) 5, 1964), 熊本県萪池郡西合志 町九州農試（標高 $75 \mathrm{~m}$ ) のクローバ類, カワラケツメイ からはサツマイモネコブセンチュウ，ジャワネコブセン チュウが検出されている(後藤, 未発表)。これらにくら べると，阿蘇九重地区の高標高（650 m以上）の自然草 地，人士草地から見出されたネコブセンチュウがすべて キタネコブセンチニウであったことは，特異といわねば ならない。

これらの草地にはイネ科植物が普遍的で，採集にあた ってはそのほかのマメ科植物の根辺土境をも可能なかぎ り含ませたので*，この調查結果は材料の棌集法（植生） で偏ったとは考无られない。

日本では北海道の畑地，草地のネコブセンチニウはキ タネコブセンチュウであり（一F，1955，一戸ら，1956， 湯原，1967，湯原，1969），この線虫は九州にも広く分 布するが，サッマイモネコブセンチュウは，伊藤(1966) によればその分布は表日本では茨城県, 䛨日本では新潟

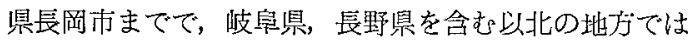
見出されていないという。

Dao（1970）がヴェネズエラ（低地）およびオランダ （温室内）加ら得た材料について行なった実験による と，M. incognita は産地により温度反応を若干珙にす るが (thermotype を談める)，ふ化，ゴール形成，繁

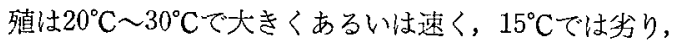
$10^{\circ} \mathrm{C}$ ではその程度が低かった。卵は $5^{\circ} \mathrm{C}$ に15日間置く と，低温の害を受けた。一方 M. hapla (ヴェネズェラ 高地産およびオランダ慰外産）は低温に強く, $5^{\circ} \mathrm{C}$ 水 中および $0^{\circ} \mathrm{C}$ 土㙵中でよく生き残った。しかし高温を 好むことは $M$. incognita に劣らず，ふ化，ゴール形

*人工草地のすべて, 自然草地の半分については, 調査 材料（土堆）にマメ科根辺土境方混入されていた（調 查法参照)。
成, 繁殖は $15^{\circ} \mathrm{C} \sim 35^{\circ} \mathrm{C}$ で行なわれ， $30^{\circ} \mathrm{C}$ 低温より好適 でさえあった。また Dao(1970) は，外来のジャガィモ

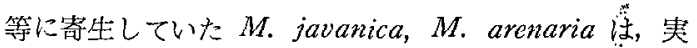
験の結果オランダの㞏外では生存を続け得なかったとい う。このようなことから，M. hapla は低温に強く，高 温を嫝わないので，その南北，垂淔分布の籁囲が広い が, M. incognita, M. javanica 等は高温に適するが 低温に弱く，ある程度以上の高地には分布しえないので あろうと考元られる。

ネコブセンチュウの種の南北，垂值分布に関する気候 (温度) 要因説は広く受计いれられており, 阿蘇九重の 高原地区の場合もそれに適合するように思和るが，決 定までには，九州の他の高地にお怰るネコブセンチュウ 各種の分布実㞸, 九州産ネコブセンチュウ各種の温度関 連生態，阿蘇九重地区の温度環境の詳細，この地区にお ける他の線虫属に関する專情を知りたい。また，大分県 久住町の県睃産試験埸の耕地（トウモロコシ跡）からサ ツマイモネコブセンチュウ(?)が検出されている。耕地 と草地では，線虫の伝播に関するちがいについても検討 が必要である。

\section{摘要}

1）熊本県，大分県にまたがる阿蘇九重地区 6 力町村 の調查で，標高 $650 \mathrm{~m}$ 以上の滈原の自然草地 9 地点，人 工草地（耕起造成草地）4地点加得られたネコブセン チュウはことごとくキタネコブセンチュウであった。 熊本県阿蘇郡小国町の三共牧場にお汀る集中調伹でも, 検出されたネコブセンチュウはすべてキタネコブセンチ ニウであった。このことは，ネコブセンチュウ数種の分 布する，九州の低地の畑地，草地にくらべて特異であ る。

2）その原因を考察し，気候（温度の）の影響による ものであろうとしたが，なお検討の余地がある。前記の 阿蘇九重地区の高原草地の年平均気温は $12^{\circ} \mathrm{C}$ 以下であ る。

\section{引用文献}

1) Dao, F. (1970): Mededelingen Landbouwhogeschool Wageningen, $70-2,181 \mathrm{pp}$. 2) 後藤重喜 - 岩崎㫪离・ II越隹 (1964)：宮崎県農試研究報告, 3, 1-7 3) 一㞋稔 $(1955)$ ：応動, 20,75-82 4) 一戸稔 . 湯原踣(1956)：日生態会訫，6，24-28 5) 伊藤喜隆(19 $66)$ : 昭41応動昆大会講要，306）前原宏 $(1960)$ ：九病 虫研会報（講要），6，105-106 7) 宮崎県農試(1960): 昭33年度農林省応用研究成綃書，79pp. 8) 横尾多美男

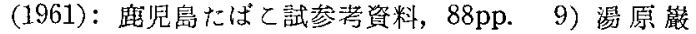
(1967)：北農，34，41-52 10）湯原㦑(1969)：昭44応 動昆大会講要, 8 